\title{
DEVELOPING MATHEMATICS LEARNING TOOLS TO STIMULATE CRITICAL THINKING
}

\author{
Dafid Slamet Setiana $^{1 *}$, Rusgianto Heri Santosa ${ }^{2}$, Rita Eka Izzaty ${ }^{3}$ \\ and Tutut Herawan ${ }^{4}$ \\ ${ }^{1}$ Pascasarjana, Universitas Negeri Yogyakarta. Jalan Colombo No. 1, \\ Karangmalang, Yogyakarta 55281, Indonesia \\ ${ }^{2}$ Jurusan Pendidikan Matematika, Universitas Negeri Yogyakarta. Jalan Colombo \\ No. 1, Karangmalang, Yogyakarta 55281, Indonesia \\ ${ }^{3}$ Jurusan Psikologi, Universitas Negeri Yogyakarta. Jalan Colombo No. 1, \\ Karangmalang, Yogyakarta 55281, Indonesia \\ ${ }^{4}$ Universitas Negeri Yogyakarta. Jalan Colombo No. 1, Karangmalang, \\ Yogyakarta 55281, Indonesia \\ 11dafid.slamet@student.uny.ac.id, ${ }^{2}$ santosa_rh@yahoo.co.id, \\ 3rita_ekaizzaty@uny.ac.id, ${ }^{4}$ tututherawan@uny.ac.id \\ *dafid.slamet@student.uny.ac.id
}

\begin{abstract}
The purpose of this research was to produce the valid mathematics learning devices to stimulate critical thinking. The developmental model used in this study was a model developed by Borg and Gall as a major developmental model. It was modified by Dick and Carey model and Kemp (1994: 9) model (Real Research and Development). The subjects of the study were senior year students in science (IPA) class from six state senior high schools in Pacitan. The data were collected through test, questionnaire, observation, and interview. The data were analyzed using content and descriptive analysis techniques. The result of the research consisted of module, lesson plan, student worksheet, and a mathematics test on geometry transformation material that had been validated. The analysis results showed that the product met the validity criteria, as indicated by the percentage of $100 \%$ of expert judgments included in the valid category thus the product is worth of using.
\end{abstract}

Keywords - Learning Device, Math, Critical Thinking

\section{INTRODUCTION}

High-quality human resource is an important factor for development in this globalization era. Experience in many countries shows that quality of human resource is more important than abundant natural resources. This is in accordance with the notion of Notoatmodjo [1] stating that the main assets of a nation include both natural and human resources (HR). However, human resource plays a more decisive role in management of natural resources. This opinion is reinforced by Hagen [2] that human resources therefore have an important role in the national development. Hence, to improve the quality of humans as development investment is in need; most importantly for Indonesia.

Received: April 11, 2019

Reviewed: June 17, 2019

Accepted: July 19, 2019

* Corresponding Author 
Indonesia is ranked in the bottom line list of Human Development Index (HDI). Indonesian HDI in 2014 was positioned $110^{\text {th }}$ from 188 countries [3]. Indicators in determining HDI are health, wealth and education. In this case, education is one of the crucial roles. Qualified human resources can only be realized with quality education [4, 5]. Therefore, efforts to improve the educational quality is inevitable in order to rise the quality of human resources of Indonesia.

In Indonesia, the quality of education is not comparable to neighbor countries. The study of international institutions shows that Indonesian students' mathematical literacy is lower compared to other countries. It was based on the study of Trends in International Mathematics and Science Study (TIMSS) and Program for International Student Assessment (PISA) which put Indonesia at low position of $45^{\text {th }}$ amongst 50 countries in TIMSS and $63^{\text {rd }}$ from 70 countries in PISA $[6,7]$. The low achievement in TIMSS and PISA is related to the inability to solve mathematical tests. Such tests are difficult for pupils because the type question is non-routine questions. To solve it, students need further thought because the procedure is not as clear as studied in the class [8].

Indonesian students are not trained to work on non-routine questions. Learning is dominated by simple question and clear solution namely "problems with a single solution"; not open-ended questions. Such questions are also known as routine question which can be solved by the procedures learned in classrooms [8] while the open-ended questions require high-level and critical thinking skills to provide solutions [9]. As a result, Indonesian students are lack of skills such as (1) critical thinking, (2) identifying new problems, (3) developing materials or ideas, and (4) problem solving using proper mathematical procedures. From various abilities of high-level thinking, Indonesian students are specifically limited with critical thinking.

Critical thinking is a way of thinking and a set of skills to encourage an informed, conscious, systemic, considered and logical approach to decide what to be believed or conducted. Critical thinking leads to valid arguments and conclusions, as well as resistance to criticism [10]. Critical thinking is also defined as a process of intellectual discipline of active conceptualization in applying, analyzing, synthesizing, and/or evaluating the generated information through observation, experience, reflection, reasoning, or communication, as a set of guides to believe and put efforts [11].

Critical thinking is a learned skill that requires instruction and practice [12]. Because critical thinking is a mental habit requiring students to rethink about their thinking and a process of improvement, it requires students to use higher order thinking skills not to memorize data or accept what they read or are told without critically thinking about it $[11,13,14]$. Therefore, critical thinking is a product of education, training, and practice [12].

According to Facione [15] the most basic concept of critical thinking is the ability of interpretation, analysis, evaluation, inference, explanation and self-regulation. Critical thinking skills by Onosko and Newmann [16] may challenge the students to interpret, analyze or manipulate information. Therefore, the critical thinking is needed when we try to understand something of information that will be used for the triggering ideas [17]. Similarly, critical thinking requires students to use new information or manipulate existing knowledge and information to obtain reasonable responses to new situations [18, 19]. Ennis [17] contended that critical thinking is a reflective thinking that focuses on patterns of decision making about what must be believed and what must be done. In the context of mathematical problem solving, Krulik and Rudnick [20] stated that critical thinking is analytical thinking and reflection that involving testing activities, questioning, connecting and evaluating all aspects of a situation or problem. Critical thinking skills are very important in learning mathematics because these skills can improve the quality of learning to be more meaningful, therefore should be a systematic way to develop such skills through mathematics learning in school [21]. 
Based on some previous definitions, it can be concluded that critical thinking is a process of analyzing, synthesizing, and/or evaluating the collected information through observation, experience, reflection, reasoning, or communication to generate valid and strong arguments and conclusions resistant to criticism. A valid conclusion should be supported by strong evidence as Pithers and Soden [22] suggested that critical thinking should be able to present evidence to support arguments. It is also expressed by Moore and Parker [23] by giving an illustration that critical thinking is an exercise for processing information to achieve credible, logical, and responsible results.

Critical thinking skill is vital because it enables students to deal effectively with social, scientific, and practical problems [24]. Simply put, students having a proper degree of ability to think critically and to the solve problems successfully. Having knowledge or information is not enough. To be effective in the workplace (and in the personal live), students must be able to solve problems to make effective decisions, and they must be able to think critically.

Lecture and memorization do not promote critical thinking. Instructional strategies that employ students' higher order thinking skills lead to improved critical thinking skills [2527]. Critical thinking skills should be part of student's learning and schools should be responsible to develop and evaluate critical thinking skills through teaching and learning process [28].

The concept of mathematics is comprehended due to the process of deep critical thinking. then, it to be developed in the learning of mathematics. Result of a study depicts that there is a relationship between conceptual understanding and critical thinking skills in learning [29]. Critical thinking skill can be developed through a process of mathematics learning because it has a structure and strong, clear connectivity between its concepts; and students who learn mathematics are potential to be rational, logic and critical [30, 31].

This is in line with the objectives of mathematical education in schools that emphasize children to build skill of reasoning and characteristic. Therefore, the learning process of mathematics is influenced by the ability of critical thinking, and those two things (learning mathematics and critical thinking) are, in fact, inseparable. Mathematical material is well understood only through critical thinking and critical thinking can be trained through the learning of mathematics. Mathematical material is composed by interrelated concepts to solve mathematical problem, it is required one or more concepts [32]. To understand the concepts of mathematics and to solve problems, it requires certain level of critical thinking ability. Critical thinking is also an effective means in enhancing students' understanding of Mathematics concepts because the skill offers interpretation, analysis, evaluation, and presentation of date in a logical and sequence manner [32, 33].

In the absence of critical thinking, students are not in maximum state in solving problems and understanding the concept of mathematics. On the other hand, to be able having the ability of thinking critically, students must be trained through learning of mathematics, for example by solving the open-ended problems. Critical thinking skill in mathematics is closely related with problem solving in mathematics, as with mathematical open-ended problems and contextual problem will challenge students to solve the problem up to encourage students to mathematical thinking [34, 35]. Thus, it is clear that there is a relationship between the learning process of mathematics and the critical thinking. Efforts to stimulate critical thinking skills of mathematics have become the main agenda in the curriculum of mathematics education worldwide [35-37]. Many researchers have shown that the development of critical thinking skills can improve achievement in mathematics [33, 35, 38-40].

Efforts to stimulate critical thinking in this study is based on Operant Conditioning Theory initiated by B.F. Skinner [41]. Operant conditioning is a response to its environment followed by certain stimuli. Such a stimulus is called reinforcement because of strengthening the previous response. The mechanisms of operant conditioning are: 
First, reinforcement or positive reward, in which case the response that is rewarded will be likely repeated. Second, negative reinforcement, in which the run-away response from unexpected pain will be likely recurring. Third, discontinuation or without reinforcement i.e., a response without reinforcement is unlikely to be repeated [18].

Skinner disagrees with punishment instead he believes in what he calls a negative booster. Punishment sometimes precludes the positive behavior of the punished object [42]. The application operant conditioning principle, in the absence of punishment in education, does not mean that it teaches uncivilized education, but emphasizes that sanction or punishment actually breeds unexpected behavior [43]. The difference between negative reinforcement and the punishment is that negative reinforcement increases the probability of an occurrence of behaviors while the penalty lowers them [44].

The critical thinking is exclusively imperative; thus, it needs to be developed into a learning device. This learning device is strived to stimulate the students' critical thinking ability. The main critical thinking theory used in this learning device is developed by Ennis [17]. Ennis explained that critical thinking is a process that aiming to make reasonable decisions so that the presumption considered as self-truth can be performed correctly [17]. There are six basic elements in critical thinking abbreviated as FRISCO (Focus, Reason, Inference, Situation, Clarify and Overview). Ennis also mentioned that critical thinking is related to the learning of mathematics in the classroom. It was divided into two indicators: general and content indicators [17]. Yet, in brief, these indicators can be grouped into five major activities which are elementary clarification, basic support, interference, advanced clarification, and strategy and tactics.

There are also other theories applied in the device. One, theory of Bloom's Taxonomy [45], been revised by Anderson \& Krathwohl [46], contains six stages of thinking: remembering, understanding, applying, analyzing, evaluating, and creating. Two, Fink Theory's [47]; it contains five steps in converting students to critically think, namely: determining learning objectives, teaching through questions, prerequisite practice, reviewing, improving, developing, and providing feedback and assessment. Three, Potts and Bonnie's theory [48]; it describes the characteristics of critical thinking in learning including: improving interaction among learners, asking open-ended questions, providing adequate time for learners to reflect upon questions or problems, and teaching for transfer (to teach how to use of the new acquired abilities to solve other incidents of their own experience). As for the questions predation, Krulik and Rudnick's Theory is suitable depicting the development of students' critical thinking skills through answering innovative questions, such as: "What's another way?", "What if ...?", "What's wrong?", "What would you do?" [20].

Based on theories described above, the efforts to stimulate the critical thinking in learning can be summarized as follows:(1) the existence of strengthening employing either positive or negative reinforcements from the students' responses, (2) the programmed, linear materials through a module system, (3) the diagnostic-emphasized test, (4) the student active learning process, (5) the absence of punishment system, (6) the priority on directions to accomplish objectives, (7) learning outcomes and feedback will be given to the students immediately, (8) providing simple explanations, (9) building basic skills, (10) making conclusions, (11) giving further explanations, (12) organizing strategy and tactics, (13) determining learning objectives, (14) increasing interaction between pupils, (15) asking open-ended, innovative questions, (16) allocating time for students to reflect, (17) accommodating students with feedback and assessment of whole learning, and (18) teaching for transfer. This way, the effort to stimulate the critical thinking in learning will be effective.

From the description above, the authors intend to conduct a research on the development of mathematics learning device to stimulate critical thinking. The research problems are: (1) "How to develop the mathematics learning device to stimulate critical thinking?" and (2) "How is the valid mathematics learning device to stimulate critical 
thinking?". Hence, this research aims to (1) describe the process of the mathematical learning device development and (2) producing it to stimulate critical thinking.

\section{MATERIALS AND METHODS}

\subsection{TYPE OF RESEARCH}

This study was a research and development (R\&D) using model developed by Borg and Gall [49] as a major development model, and was modified by other models such as Dick and Carey [50] as well as Kemp [51]. Furthermore, the modification of the developmental model resulting a new model called RRD (Real Research and Development). RRD model is mostly similar with the Borg and Gall model, but it is simpler with only five main stages.

\subsection{TIME AND PLACE OF RESEARCH}

The study was conducted from October 2016 to January 2017. The sites were in six state senior high schools (Indonesian term is Sekolah Menengah Atas Negeri or SMAN) in Pacitan, East Java, Indonesia. The schools were SMAN 2 Pacitan, SMAN Punung, SMAN Tulakan, SMAN 1 Ngadirojo, SMAN 2 Ngadirojo and SMAN Tegalombo.

\subsection{TARGET OR SUBJECTS OF RESEARCH}

The research subjects were the students in senior year; class XII of IPA (science) in six senior high schools in Pacitan, East Java. In each school, the randomly sampling techniques were used.

\subsection{PROCEDURES OF RESEARCH}

The RRD developmental model includes five main stages:

a. Collecting information, it consists of planning the definition of ability, formulation of objectives, and determination of learning sequence.

b. Developing the product, it includes the preparation of the learning and evaluation devices.

c. Preliminary testing and revision; in this stage, the file is sent to be validated by validators, and then conducting revision required.

d. Operational testing and revision; in this stage, the test is performed in the subject schools. Then, the revision of final product while collecting data through observation, interview, self-assessment questionnaire and peer assessment questionnaire.

e. Disseminating and implementation the final product that had been tested.

\subsection{RESEARCH DATA, INSTRUMENTS, AND DATA COLLECTION TECHNIQUES}

The research data were qualitative and quantitative data. Qualitative data was collected using instruments of interview guidance and validation sheets. The quantitative data was collected using instruments of Focus Group Discussion activity, observation sheet, the questionnaire, and critical thinking ability test.

The technique of collecting data was through observation when conducting the operational test. Interviews and data collection through questionnaires were conducted after the operational tests. Interviews were conducted to the subjects of teachers and some 
students. The questionnaire was given to all of the students as the research subjects. The critical thinking skills test was held in the last meeting.

\subsection{DATA ANALYSIS TECHNIQUE}

The data collected were analyzed with two techniques: the content analysis and the descriptive analysis. Content analysis was primarily to analyze the learning device using the result data from the experts' reviews and the mathematics subject teachers. Numeric data were assessed and interpreted in accordance with the predetermined criteria. The data in form of sentences were grouped, simplified, and then coded. The data from field research (collected through observation, interview, documentation, self-assessment questionnaire, and peer assessment questionnaire) were analyzed and interpreted in accordance with the established research objectives.

\subsection{VALIDITY TEST OF OUTPUT PRODUCTS}

The developed learning device was determined as valid if all aspects of the validity assessments were validated by the validators. Thus, the results of the data analysis not meeting the validity categories would be considered to revision of the learning device before the trials for the students. The feasibility of learning tools is assessed in a range of 1 to 4 . Data analysis results are categorized as follows: average $>3.20$ is very valid, 2.40 $<$ average $\leq 3.20$ is valid, $1.60<$ average $\leq 2.40$ is valid, $0.80<$ average rata $\leq 1.60$ is less valid, and $\leq 0.80$ is invalid.

\section{RESULTS}

The data analysis in this research consisted of the data analysis of validity of mathematics learning device to stimulate the critical thinking. Based on the validation results from the experts, the feasibility of the mathematics learning device being developed can be identified. The validation of the mathematics-learning device to stimulate the critical thinking in general could be seen in Table I. The analysis of the prevalence and assessment aspects are presented in Table II.

Table I. The Result of the Validation of the Mathematics Learning Device to Stimulate Critical Thinking

\begin{tabular}{|c|c|c|c|}
\hline Number & Validated Products & $\begin{array}{c}\text { Validity } \\
\text { Assessment }\end{array}$ & Appropriateness \\
\hline $\mathbf{1 .}$ & Module & Valid & $\begin{array}{c}\text { Worthof use with minor } \\
\text { revision }\end{array}$ \\
\hline $\mathbf{2 .}$ & Lesson Plan & Valid & $\begin{array}{c}\text { Worth of use with minor } \\
\text { revision }\end{array}$ \\
\hline $\mathbf{3 .}$ & Student Worksheet & Valid & $\begin{array}{c}\text { Worth of use with minor } \\
\text { revision }\end{array}$ \\
\hline $\mathbf{4 .}$ & Instrument TEst & Valid & $\begin{array}{c}\text { Worth of use with minor } \\
\text { revision }\end{array}$ \\
\hline & & & \\
\hline
\end{tabular}


Tables II. The analysis of the prevalence and based on aspects of the assessment

\begin{tabular}{|c|c|c|c|c|c|c|}
\hline No & Description & Module & $\begin{array}{l}\text { Lesson } \\
\text { Plan }\end{array}$ & $\begin{array}{l}\text { Student } \\
\text { Work } \\
\text { sheet }\end{array}$ & $\begin{array}{l}\text { Instrume } \\
\text { nt Test }\end{array}$ & $\begin{array}{c}\text { Validity } \\
\text { Assessme } \\
\text { nt }\end{array}$ \\
\hline \multirow[t]{5}{*}{1.} & Aspects of Content & & & & & \multirow{4}{*}{$\begin{array}{l}\text { Very } \\
\text { Valid }\end{array}$} \\
\hline & $\begin{array}{l}\text { a. Aspects of } \\
\text { critical thinking } \\
\text { are complete }\end{array}$ & 3.00 & 4.00 & 3.50 & 4.00 & \\
\hline & $\begin{array}{l}\text { b. Statement of } \\
\text { every aspect of } \\
\text { critical thinking } \\
\text { is complete }\end{array}$ & 3.50 & 4.00 & 3.50 & 4.00 & \\
\hline & $\begin{array}{l}\text { c. The device is } \\
\text { easy to use }\end{array}$ & 4.00 & 4.00 & 4.00 & 3.50 & \\
\hline & Average & 3.50 & 4.00 & 3.67 & 3.83 & \\
\hline \multirow[t]{5}{*}{2.} & Aspects of Language & & & & & \multirow{4}{*}{$\begin{array}{l}\text { Very } \\
\text { Valid }\end{array}$} \\
\hline & $\begin{array}{c}\text { a. Using sentences } \\
\text { according to } \\
\text { Indonesian rules }\end{array}$ & 4.00 & 4.00 & 4.00 & 4.00 & \\
\hline & $\begin{array}{l}\text { b. Statements used } \\
\text { communicatively }\end{array}$ & 4.00 & 4.00 & 4.00 & 4.00 & \\
\hline & $\begin{array}{c}\text { Sentences and } \\
\text { words used are } \\
\text { easy to } \\
\text { understand. }\end{array}$ & 4.00 & 4.00 & 4.00 & 4.00 & \\
\hline & Average & 4.00 & 4.00 & 4.00 & 4.00 & \\
\hline 3. & General Assessment & A & A & A & A & $\begin{array}{l}\text { Very } \\
\text { Valid }\end{array}$ \\
\hline
\end{tabular}

Based on the Table I it could be seen that the validator rated all of the products with very valid. The developed mathematics learning device was feasible to be used for trials after revisions based on the comments and suggestions of validators.

Table II shows the average score of very valid amongst all learning devices from various aspects. The assessments of module are (1) content aspect with the score of 3.50, (2) language aspect with the score of 4.00, and (3) general assessment with A category. Moreover, the assessment scores of RPP are (1) content aspect is obtained with 4 categories is very valid, (2) the language aspect is got an average of 4 with the category is very valid, and (3) the general assessment get the value of A with the category is very valid. Assessment of LKS, namely (1) content aspect obtained 3.67 with very valid category, (2) language aspect got average 4 with category very valid, and (3) general assessment get value A with category very valid. Assessment of the test instruments, namely (1) the content aspect is 3.83 with the category is very valid, (2) the language aspect is got an average of 4 with the category is very valid, and (3) the general rating get the value of A with the category is very valid. 


\section{DISCUSSION}

Measuring content validity of instruments is crucial $[52,53]$. The validity test of this research emphasizes on content and construct validities. Content validity is the compatibility of the foundation components of the product development while the construct validity is the linkage of all components in the product development.

The content validity was declared valid by the validators because the developed learning device had been in accordance with the material that should be presented. To test the construct validity, experts can be employed (judgment validity) [54].

Based on the validation result, it can be concluded that mathematics learning tool to stimulate critical thinking was very valid based on 3 aspects of validity indicators. In content aspect, the learning tools were suitable with research objectives in order to stimulate critical thinking, therefore it contains aspects and learning stages that can foster critical thinking skills for pupils.

Preparation of learning modules was tailored to the Core Competence (KI) and Basic Competence (KD) Curriculum of 2013 at high school level of class XII IPA. Preparation of RPP was based on the stages of learning activities obedience with Curriculum of 2013. The basis of the learning stages preparation in the RPP combined theory of critical thinking by Ennis [17], Bloom's Theory [45] revised by Anderson \& Krathwohl [46], Theory Fink [47], as well as Potts and Bonnie Theory [48]. Ennis's theory as the main one includes FRISCO (Focus, Reason, Inference, Situation, Clarify, and Overview). Meanwhile, Bloom's Taxonomy covers six stages of thinking and The Fink Theory comprises five steps to transform students to critically think. Furthermore, Potts and Bonnie Theory encompasses the characteristics of critical thinking learning. Lesson plan preparation applied Theory of Operant Conditioning developed by Skinner [41] comprising stimulation stage. Student worksheet preparation and critical thinking tests were based on the Theory of Krulik and Rudnick [20] on developing students' critical thinking skills through solving innovative questions.

Based on the presentation, learning tools were consistent with the criteria of the standardized learning tools preparation, and presented systematically for convenient use. In the learning module, the interrelationships between materials or topics were carefully explained, then each topic was presented carefully with a strategy to present in this particular order: descriptions, examples and exercises. The sequence of module contents made it easier for students to learn and to accustom for critical thinking [55].

Lesson plan was arranged systematically and in detail to facilitate teachers applying it in the learning process. To present a subject or a topic, teachers needed examples and illustrations so that student can comprehend faster. Based on these, the worksheet was accompanied by drawings, illustrations, examples of problems and clear exercise questions as well as providing it with places to solving the problem. The test instrument was structured matching with the objective to discover the effectiveness of the learning device to stimulate critical thinking. Thus the test instrument contains questions with multiple completion techniques, yet still easily understandable.

Based on the language aspects, the learning device was developed consistent with the ability of students in understanding the content and language of each product. In developing learning tools, especially for modules, worksheet and test instruments, the utilization of language had become a significant factor. Things to consider carefully in using language included the selection of diction, the application of effective sentences and meaningful paragraphs; they significantly effect the level of understanding and the benefits of learning tools.

Albeit the contents of learning tools were meticulous, consistent in formatting and packaged sophisticatedly, if the language was difficult to grasp by students, then the learning device will not be effective [55]. In this study, learning tools were expected to stimulate critical thinking skills of high school students, to motivate them in reading, to 
independently do their tasks and homework, and to generate curiosity in exploring further and beyond of the topics learned in class.

\section{CONCLUSIONS}

Based on the results and discussion, the following conclusions were generated: This research developed a mathematics-learning device for senior year students in high school in a science major to stimulate critical thinking skills. The learning device was developed using the Borg and Gall development model as the main development model, it was modified with the Dick and Carey model and the Kemp model. It was named by the Real Research and Development (RRD) development model. The model included five stages. They were collecting information, Developing the product, preliminary testing and revision, Operational testing and revision while collecting data, and Disseminating and implementing the product.

The products were a lesson module, a lesson plan, worksheet, and the instruments of the critical thinking skill test. This research produced a valid mathematical learning device to stimulate a critical thinking. After going through the validation stage by the experts, the product is in very valid category.

\section{References}

[1] Notoatmodjo S., "Kesehatan dan Pembangunan Sumber Daya Manusia", Kesmas: National Public Health Journal, 2(5), (2008): 195-199.

[2] Hagen M. and D. Bouchard, "Developing and Improving Student Non-Technical Skills in IT Education: A Literature Review and Model", in Informatics. Multidisciplinary Digital Publishing Institute, (2016).

[3] AfBD O., "UNDP, 2015. African Economic Outlook 2015: Regional Development and Spatial Inclusion", Paris, OECD, available online http://dx. doi. org/10.1787/aeo-2015-en (retrieved 20 February 2017).

[4] Tjalla A., "Statika pendidikan", Jakarta: Depdiknas, (2008).

[5] Wolff L.-A., P. Sjöblom, M. Hofman-Bergholm, and I. Palmberg, "High Performance Education Fails in Sustainability?-A Reflection on Finnish Primary Teacher Education", Education Sciences, 7(1), (2017): 32

[6] Jones L.R., G. Wheeler, and V.A. Centurino, "TIMSS 2015 science framework", TIMSS, (2015): 29-59.

[7] Pisa O., "Draft Science Framework", (2015).

[8] Nyimas A., "Pengembangan Pembelajaran Matematika SD", Jakarta: Direktorat Jenderal Pendidikan Nasional, (2007).

[9] Dahlan J.A. and A. Rohayati, "Implementasi Strategi Pembelajaran Konflik Kognitif Dalam Upaya Meningkatkan High Order Mathematical Thinking Siswa", Jurnal Pendidikan. 13(2), (2012): 65-76.

[10] Onions P., "Thinking Critically An Introduction", Online),(http://patrickonions. org, diakses 20 Februari 2013). (2009).

[11] Scriven M. and R. Paul, "Defining Critical Thinking", The critical thinking community: foundation for critical thinking, (2015).

[12] Snyder L. G. and M. J. Snyder, "Teaching critical thinking and problem solving skills", The Journal of Research in Business Education, 50(2), (2008): 90.

[13] Schafersman S.D., "An introduction to critical thinking", Retrieved May 13, 2009, (1991).

[14] Tempelaar D.T., "The role of metacognition in business education", Industry and Higher Education, 20(5), (2006): 291-297.

[15] Facione P.A., "Critical Thinking: What It Is and Why It Counts", (2013).

[16] Onosko J.J. and F.M. Newmann, "Creating more thoughtful learning environments", Creating powerful thinking in teachers and students: Diverse perspectives, (1994): 27-49.

[17] Ennis R., "Critical thinking", New Jersey: Prentice-Hall Inc. (1996).

[18] Lewis A. and D. Smith, "Defining higher order thinking", Theory into practice, 32(3), (1993): 131-137.

[19] Perkins C. and E. Murphy, "Identifying and measuring individual engagement in critical thinking in online discussions: An exploratory case study", Journal of Educational Technology \& Society, 9(1), (2006).

[20] Krulik S. and J.A. Rudnick, "Innovative tasks to improve critical and creative thinking skills", from Developing Mathematical reasoning in Grades K-12, (1999): 138-145.

[21] Cobb P., T. Wood, E. Yackel, and B. McNeal, "Characteristics of classroom mathematics traditions: An interactional analysis", American educational research journal, 29(3), (1992): 573-604.

[22] Pithers R.T. and R. Soden, "Critical thinking in education: A review", Educational research, 42(3), (2000): 237-249. 
[23] Moore B.N., R. Parker, and N. Rosenstand,"Critical thinking", McGraw-Hill Education, (2011).

[24] Shakirova D., "Technology for the shaping of college students' and upper-grade students' critical thinking", Russian Education \& Society, 49(9), (2007): 42-52.

[25] Duplass J.A. and D.L. Ziedler, "Critical thinking and logical argument", Social Education, 66(5), (2002): M10-M10.

[26] Hemming H.E., "Encouraging critical thinking:" But... what does that mean?"", McGill Journal of Education. 35(2), (2000): 173.

[27] Wong D., "Beyond control and rationality: Dewey, aesthetics, motivation, and educative experiences", Teachers College Record. 109(1), (2007): 192-220.

[28] Firdaus F., I. Kailani, M.N.B. Bakar, and B. Bakry, "Developing Critical Thinking Skills of Students in Mathematics Learning", Journal of Education and Learning (EduLearn), 9(3), (2015): 226-236.

[29] Alatas F., "Hubungan pemahaman konsep dengan keterampilan berpikir kritis melalui model pembelajaran treffinger pada mata kuliah fisika dasar", Edusains, 6(1), (2014): 87-96.

[30] Aizikovitsh-Udi E. and M. Amit, "Developing the skills of critical and creative thinking by probability teaching", Procedia-Social and Behavioral Sciences, 15, (2011): 1087-1091.

[31] Rajendran N.,"Teaching \& Acquiring Higher-Order Thinking Skills: Theory \& Practice", Penerbit Universiti Pendidikan Sultan Idris, (2008).

[32] Vitasari P., T. Herawan, M.N.A. Wahab, A. Othman, and S.K. Sinnadurai, "Exploring mathematics anxiety among engineering students", Procedia-Social and Behavioral Sciences, 8, (2010): 482-489.

[33] Chukwuyenum A.N., "Impact of critical thinking on performance in mathematics among senior secondary school students in Lagos state", IOSR Journal of Research \& Method in Education, 3(5), (2013): 18-25.

[34] Henningsen M. and M.K. Stein, "Mathematical tasks and student cognition: Classroom-based factors that support and inhibit high-level mathematical thinking and reasoning", Journal for research in mathematics education, (1997): 524-549.

[35] Mathematics N.C.o.T.o.,"Principles and standards for school mathematics", Vol. 1. National Council of Teachers of (2000)

[36] Innabi H. and O. El Sheikh, "The change in mathematics teachers' perceptions of critical thinking after 15 years of educational reform in Jordan", Educational Studies in Mathematics, 64(1), (2007): 45-68.

[37] Mason J., L. Burton, and K. Stacey, "Thinking mathematically", Pearson. (2010).

[38] Jacob S.M., "Mathematical achievement and critical thinking skills in asynchronous discussion forums", Procedia-Social and Behavioral Sciences, 31, (2012): 800-804.

[39] Semerci C., "The influence of critical thinking skills on students' achievement", Pakistan Journal of Social Sciences. 3(4), (2005): 598-602.

[40] Silver E.A. and P.A. Kenney, "Sources of assessment information for instructional guidance in mathematics", Reform in school mathematics and authentic assessment, (1995): 38-86.

[41] Skinner B.F., "Reflections on behaviorism and society", (1978).

[42] Schlick-Steiner B.C., F.M. Steiner, B. Seifert, C. Stauffer, E. Christian, and R.H. Crozier, "Integrative taxonomy: a multisource approach to exploring biodiversity", Annual review of entomology, 55, (2010): 421-438.

[43] Palmer J.A., "Pemikir Pendidikan dari Piaget sampai Masa Sekarang", Yogyakarta: Jendela.

[44] Santrock J., "Psikologi pendidikan.(terjemahan Tri Wibowo BS) New York", Mcgraw-Hill.(Buku asli diterbitkan tahun 2004), (2008).

[45] Bloom B.S., "Taxonomy of educational objectives. New York: David McKay Company", Inc. Google Scholar, (1956).

[46] Anderson L.W., D.R. Krathwohl, P. Airasian, K. Cruikshank, R. Mayer, P. Pintrich, J. Raths, and M. Wittrock, "A taxonomy for learning, teaching and assessing: A revision of Bloom's taxonomy", New York. Longman Publishing. Artz, AF, \& Armour-Thomas, E.(1992). Development of a cognitivemetacognitive framework for protocol analysis of mathematical problem solving in small groups. Cognition and Instruction, 9(2), (2001): 137-175.

[47] Fink L.D., "A self-directed guide to designing courses for significant learning", University of Oklahoma, 27, (2003): 11.

[48] Potts B., "Strategies for Teaching Critical Thinking. ERIC/AE Digest", (1994).

[49] Borg W.R. and M.D. Gall,"Instructor's Manual for Educational Research: To Accompany Educational Research: an Introduction", Longman, (1983).

[50] Dick W., L. Carey, and J.O. Carey, "The systematic design of instruction", (2005).

[51] Morrison G., S. Ross, and J. Kemp, "Designing Effective Instruction".

[52] Ramadhan S. and D. Mardapi, "Estimasi Kesalahan Baku Pengukuran Soal-Soal UAS Fisika Kelas XII SMA di Kabupaten Bima NTB", Jurnal Evaluasi Pendidikan, 3(1), (2015): 90-98.

[53] Yaghmaei F., "Content validity and its estimation", (2003).

[54] Riduwan M., "Belajar Mudah Penelitian Untuk Guru-Karyawan dan Peneliti Pemula", Bandung: Alfabeta, (2006).

[55] Belawati T., "Pengembangan bahan ajar", Jakarta: Universitas Terbuka, (2003). 